Article

\title{
Distance Learning Perceptions from Higher Education Students-The Case of Portugal
}

\author{
Sónia P. Gonçalves ${ }^{1, * \mathbb{C}}$, Maria José Sousa ${ }^{2} \mathbb{C}$ and Fernanda Santos Pereira ${ }^{3}$ \\ 1 Instituto Superior de Ciências Sociais e Políticas, Universidade de Lisboa, \\ Centro de Administração e Políticas Públicas, 1300-663 Lisboa, Portugal \\ 2 Departamento de Ciência Política e Políticas Públicas, Instituto Universitário de Lisboa, \\ 1649-026 Lisboa, Portugal; maria.jose.sousa@iscte-iul.pt \\ 3 Departamento de Ciências Empresariais, Instituto Politécnico de Beja, 7800-295 Beja, Portugal; \\ fernanda.pereira@ipbeja.pt \\ * Correspondence: spgoncalves@iscsp.ulisboa.pt
}

Received: 31 October 2020; Accepted: 7 December 2020; Published: 10 December 2020

check for updates

\begin{abstract}
This research study examines the attitudes of Portuguese higher education students regarding compulsory digital and distance learning university courses during the second semester of the academic year 2019-2020 during the COVID-19 pandemic. The methodology was quantitative, being the undergraduate and postgraduate students surveyed to find their perceptions about distance and online education in Portugal. The findings of the study highlighted the relationship between distance and online learning. The key concern of the respondents is related to the formal and contextual dimensions of the online class regime. The values examined, taken as a whole, allow us to conclude that with this teaching regime, in terms of awareness, there is acceptance and benefit. The sense of ambiguity in which this transformation took place, as well as the climate surrounding this phase, are worth noting. The teaching and evaluation methodologies used have been embraced and show a very wide range of choices on the part of the teaching teams and the students' various interests, just as in the teaching regime of the classroom. The fact that students feel the need for face-to-face classes, however, is of great importance for practical and laboratory classes. This reality, which is a challenge to face in the future, is hard to overcome.
\end{abstract}

Keywords: distance learning; higher education; online learning; digital pedagogies; students

\section{Introduction}

\subsection{Conceptualization of Distance and Online Learning}

In the literature, distance and online learning is a dynamic concept with several different interpretations. Some characterize digital learning with unexpected outcomes as an unplanned and implied process [1-3] utilizing many types of technical devices, such as smartphones, tablets, computers, and others. In the context of this definition, this study aims to analyze the impacts of distance learning on students during the COVID-19 pandemic in the second semester of the academic year 2019-2020, but also the process itself. The goal during that period was to limit meetings involving physical contact in an effort to reduce the spread of the COVID-19 virus. These conditions had implications for the effectiveness of the learning process in higher education [4,5].

In literature, based on diverse studies realized during 2020, the main platforms used to teach was Zoom, Microsoft Teams, and Google Classroom, and the classes become to be too intense for the students, with too many assignments, and a big concern related to laboratory classes. However, activities as Chatting, Forum, Choice, and Assignment, could be more structured, and used as a support for the 
distance learning process, but were not implemented as it should be to facilitate the learning process and to increase the learning outcomes [6,7].

\subsection{Distance Learning in a Pandemic Context}

The possibilities of increasingly interactive resources in the globalized world have changed the concept of communication and the sharing of education linked to innovative technologies. Since the technology linked to communication contributes to access to education and this has been expanded through digital communication networks. The innumerous paths are taken by innovation linked to technology point to different realities and orientations in the process, new methods in the educational context [4]. Over the years educational methodologies and methods have shifted. Today, in addition to expanding its output and thereby supporting people with disabilities, the instructor has engagement technology, such as interactive boards, online conferences, and other resources to strengthen the teaching and learning process [2,3]. The development of technology has been inspired by many of the "new" ways of learning and teaching. Digital instruments have contributed to the increasing development and distribution of information as strategies that provide tools. The Internet allowed new forms of computer-based learning, with virtual classrooms [8], a scenario guided by technology convergence that brought about revolutionary elements of learning, as it was characterized by the availability of texts, audio, and video on the same communication channel [1], allowing geographical, temporal and above all, communication barriers to be transposed. In a pandemic global situation, people are digitally linked in a knowledge-based society [9], living an educational scenario where digital education is nuclear to all levels of formal education.

Some concerns about distance learning in the pandemic situation includes the analysis of the following variables: [1-3] impacts on the academic journey; study schedule; place of study; moments of isolation; level of preparation; level of adaptation; satisfaction with the online classes format; and study time involved in the online learning process.

\subsection{Contexts, Pedagogies, and Tools for Distance Learning}

To involve students in the learning process, educators use technology, and several studies have shown signs of increased interest in learning when interactive technologies are integrated into the learning environment. It is possible to describe the pedagogical strategies to use innovations in the educational context as [8,9]: Open strategy, which provides access to information and knowledge creation for all with an emphasis on versatile content; Constructive strategy, which combines openness with its progressive construction to new spaces of knowledge; and Interactive strategy, which presupposes the development of the interactive processes that occur in the virtual environment.

Any pedagogy involving distance learning technologies must explore the different potentialities of these technologies: context, mobility, informality, appropriation of the tool by the student. They offer greater control and autonomy over learning itself [4-6]. Furthermore, it enables learning in context, that is, at the place, time, and under the conditions that the student deems most appropriate. It also allows continuity and connectivity between contexts [7]. For example, while the student moves in a certain area or during an event, he may be in constant contact and connected with his peers and with didactic content. Finally, it contributes to spontaneity and opportunism in the learning process, since the learner can take advantage of times, spaces, and any opportunities to learn spontaneously, according to his interests and needs [5].

In distance learning contexts, students are required a great degree of autonomy, passing on to them a great responsibility for their learning $[6,7]$. Learning situations are influenced by several factors [6,7]: (a) the professor is a facilitator of learning, assuming several roles simultaneously: moderator, participant, and observer; (b) the student that interacts with the professor and also with the other elements of the learning group; (c) space and time for carrying out learning in a global perspective, depending on the learning needs of each one; (d) the context of the learning that must be directed towards the student's needs. 
The main contexts of learning present in the literature are very diverse, as presented in the following Table 1:

Table 1. Distance and online learning technologies and pedagogies.

\begin{tabular}{|c|c|}
\hline Distance and Online Learning & Authors \\
\hline \multicolumn{2}{|c|}{ Online Learning Tools } \\
\hline $\begin{array}{l}\text { - E-mail } \\
\text { - Smartphone/Videochat } \\
\text { - International Communication Platform (e.g., Zoom, Google Hangouts ... ) } \\
\text { - E-Learning Platform or a similar tool } \\
\text { - Communication facilitators } \\
\text { - Conference Calls } \\
\text { - Chat - chatroom } \\
\text { - Conferences (video and audio) } \\
\text { - Electronic Mail } \\
\text { - Discussion forums }\end{array}$ & $\begin{array}{l}\text { [10] Barber, W.; King S.; Buchanan, S. (2015) } \\
\text { [11] Sousa, M.J.; Rocha, Á. (2019) } \\
\text { [12] Liyanagunawardena, T.; Lundgvist, K.; } \\
\text { Williams, S. A. (2015) } \\
\text { [13] Liwen, C.; Tung-Liang, C.; Nian-Shing, C. (2015) } \\
\text { [14] Masterman, E. (2016) } \\
\text { [15] Salmon, G.; Gregory, J.; Lokuge, D. K.; } \\
\text { Ross, B. (2015) } \\
\text { [16] Sohrabi and H. Iraj, (2016) } \\
\text { [17] Stewart, B. (2015) } \\
\text { [18] Thibaut, P.; Curwood, J. S.; Carvalho, L.; } \\
\text { Simpson, S. (2015) } \\
\text { [19] Trotskovsky and Sabag, N. (2015) }\end{array}$ \\
\hline \multicolumn{2}{|l|}{ Equipment } \\
\hline $\begin{array}{l}\text { - Desktop computer } \\
\text { - Laptop } \\
\text { - Tablet } \\
\text { - Smartphone }\end{array}$ & $\begin{array}{l}\text { [15] Salmon, G.; Gregory, J.; Lokuge, D.; } \\
\text { Ross, B. (2015) } \\
\text { [17] Stewart, B. (2015) } \\
\text { [20] Xu, H. (2016) } \\
\text { [21] McNaughton, S. M.; Westberry, N. C.; } \\
\text { Billiot, J. M.; Gaeta, H. (2014) } \\
\text { [22] Martin-Garcia, M. Serrano and Gomez, M (2014) } \\
\text { [23] Sungkur, R. K.; Panchoo, A.; } \\
\text { Bhoyroo, N. K. (2016) } \\
\text { [24] Tena, R. R.; Almenara, J. C.; Osuna, J. B. (2016) }\end{array}$ \\
\hline \multicolumn{2}{|c|}{ Pedagogical Techniques } \\
\hline $\begin{array}{l}\text { - Clarification sessions } \\
\text { - Availability of pedagogical materials in video format } \\
\text { - Availability of pedagogical materials in text format } \\
\text { - Group work } \\
\text { - Individual work } \\
\text { - Small groups discussion } \\
\text { - Lailability of pedagogical materials in audio format } \\
\text { - Pedagogical games } \\
\text { - Simulations/role play } \\
\text { - Case studie }\end{array}$ & $\begin{array}{l}\text { [8] Sousa, M.J; Cruz, R.; Martins. J.M. (2017) } \\
\text { [10] Barber, W.; King S.; Buchanan, S. (2015) } \\
\text { [25] Friend, J.; Militello, M. (2014) } \\
\text { [26] Guzman, G.; Hernandez, M.; Pirez, R. (2014) } \\
\text { [27] Kosonen, K.; Ilomaki, L.; Lakkala, M., (2015) } \\
\text { [28] Lau, K. H. (2014) } \\
\text { [29] Mantri, A. (2014) } \\
\text { [30] Moorefielf-Lang H.; Hall, T. (2015) } \\
\text { [23] Sungkur, R. K.; Panchoo, A.; } \\
\text { Bhoyroo, N. K. (2016) } \\
\text { [31] Munoz Gonzales, J. M.; Rubio, S. G.; Pichardo, M. } \\
\text { C. (2015) } \\
\text { [32] Nielsen W.: Hoban, G. (2015) } \\
\text { [33] Rai, S. S.; Gaikwad, A. T.; Kulkarni, R. V. A (2014) } \\
\text { [34] Rudow, J.; Sounny-Slitine, M. A. (2015) } \\
\text { [35] Stansbury, J. A.; Earnest., D. R. (2017) } \\
\text { [36] Unger; R.; Kulhavy, D. L.; Busch-Petersen, K.; } \\
\text { Hung, I.-K. (2016) } \\
\text { [37] Wood D.; Bilsborow, C. (2014) }\end{array}$ \\
\hline
\end{tabular}

Table 2 presents the possible evaluation methods of distance learning, identifying in the analysis of the literature:

Table 2. Evaluation Process on Distance Learning in Higher Education.

\begin{tabular}{ll}
\hline \multicolumn{1}{c}{ Evaluation method } & \multicolumn{1}{c}{ Authors } \\
\hline - Face-to-face & [23] Sungkur, R. K.; Panchoo, A.; Bhoyroo, N. K. (2016) \\
- Online through individual work & [25] Friend, J.; Militello, M. (2014) \\
- Online through group work & [27] Kosonen, K.; Ilomaki, L.; Lakkala, M., (2015) \\
- Online tests & [32] Nielsen W.: Hoban, G. (2015) \\
& [35] Stansbury, J. A.; Earnest., D. R. (2017) \\
& [37] Wood D.; Bilsborow, C. (2014) \\
\hline
\end{tabular}


All the tools present in Tables 1 and 2 can be used in learning contexts by contributing to facilitate student learning process, and toward the improvement of academic results. However, in the following analysis, it is possible to see that the students didn't use the potentialities of these tools as the pandemic situation created a special context that affected their application.

\subsection{Obstacles Involved in the Online Learning Process}

Distance learning also has several obstacles, of which the following refer [38]

1. Less student/teacher interaction, as the interaction of the student/teacher, becomes reduced since the communication is made via the Internet, originating as such a physical and/or temporal distance.

2. Less motivation and rhythm drive a lack of concentration and a lack of students' interaction.

3. It requires more time in the preparation of content and training, and excess of activities and works proposed to the students.

4. Difficulty in time management and difficulty in balancing family and academic life. L

5. Lack of technology skills by professors and students.

6. Lack of equipment by Professors and students.

7. Internet access speed and costs, as this system requires the use of the Internet as a crucial tool for communication, resulting in its use costs.

8. Bandwidth, which does not always efficiently support the transmission of content.

\subsection{Advantages Involved in the Online Learning Process}

It is also important to analyze the advantages of this type of learning, which facilitate the teaching and learning process [38]: Learn anytime and anywhere, since the materials are available twenty-four hours, and can be accessed from any location, allowing any trainee to join a given training, without the usual inconvenience; time-saving, as there is no need to travel to training, which causes so many inconveniences and becomes a barrier to training; the student learns at their own pace, and the student becomes autonomous, being responsible for their learning. He can choose the content and set their own pace, and the course contents can be reused in other courses partially or totally, with up-to-date information.

\subsection{Hypotheses}

This study aims to analyze the attitudes of Portuguese higher education students regarding compulsory digital and distance learning university courses during the second semester of the academic year 2019-2020 during the COVID-19 pandemic. The relationship between the pandemic impact and attitudes is explored regarding compulsory digital and distance learning and the intention to maintain the online format for the next year. Three main hypotheses were tested:

Hypothesis H1: There a negative correlation between the pandemic impact on the academic journey and the attitudes of Portuguese higher education students regarding compulsory digital and distance learning university;

Hypothesis H2: There a positive correlation between the satisfaction with online classes format and the attitudes of Portuguese higher education students regarding compulsory digital and distance learning university;

Hypothesis H3: Is there a significant difference between the perception of the pandemic impact on the academic journey and the attitudes of Portuguese higher education students regarding compulsory digital and distance learning university regarding the group of students that want to maintain the online format for the next school year and the group of students that don't want to maintain the online format for the next school year? 


\section{Methods}

\subsection{Data Collection Procedure}

An online survey was developed through the Google Forms platform and sent to higher education student associations with the available online contacts. The survey was active between August and October of 2020. The instrument's application lasted $10 \mathrm{~min}$ on average.

The ones who answered were informed of the anonymous and confidential nature of the collected data, noting that their participation in the survey was voluntary and there was no monetary or another kind of reward.

\subsection{Data Analysis Procedure}

The data was analyzed by SPSS software (26.0 version). The variables under study were characterized using descriptive and frequency statistics. Variables relationship were explored by Spearman Rho Correlation, and the $t$-test was used to explore the differences between the students that want and do not want to maintain the online format in the next school. year.

\subsubsection{Instrument}

The survey was presented in two sections, the first one relating to the experience of distance learning during the period of the COVID-19 lockdown, focusing on distance learning's satisfaction as well as the obstacles and advantages, and the second one was composed of a sociodemographic and academic characterization group.

\subsubsection{Participants}

The global sample included 173 university students. In terms of sociodemographic characteristics, the participants were mostly female $(n=142 ; 82.1 \%)$, single $(n=157 ; 90.8 \%)$ with an average age of 24 years old $(\mathrm{SD}=7.42)$. Majority of the ones inquired are from public universities $(\mathrm{n}=151 ; 87.3 \%)$. The most common cycle of studies is the first cycle $(n=116 ; 67.1 \%)$, next is the second cycle $(n=52$; $30.1 \%)$ and lastly is the third cycle $(n=5 ; 2.9 \%)$. From the participating scientific areas of the course, the ones that stood out were Law, Social Sciences and Services ( $n=43 ; 24.9 \%)$; Health $(n=34 ; 19.7 \%)$ and Economics, Management and Accounting $(\mathrm{n}=21 ; 12.1 \%)$. The school year the participants are in goes from the first one $(n=20 ; 11.6 \%)$; second one $(n=51 ; 29.5 \%)$; third one $(n=63 ; 25.9 \%)$; followed by the fourth until sixth one $(n=39 ; 22.5 \%)$. Only $26.6 \%(n=46)$ are working students.

\section{Results}

\subsection{Concern About the Pandemic and its Impacts on the Educational Path}

Table 3 illustrates the students' perceptions of the concern and impact that the Covid-19 pandemic will have on their academic journey. The students inquired are very concerned $(n=76 ; 43.9 \%)$ and extremely concerned $(\mathrm{n}=48 ; 27.7 \%)$ about the pandemic.

Table 3. Pandemic's impact on academic journeys.

\begin{tabular}{cccccc}
\hline $\begin{array}{c}\text { Concern about the } \\
\text { Pandemic }\end{array}$ & Frequency & $\mathbf{\%}$ & $\begin{array}{c}\text { Academic } \\
\text { Journey }\end{array}$ & Frequency & $\%$ \\
\hline Not concerned & 2 & 1.2 & No impact & 6 & 3.5 \\
A little concerned & 3 & 1.7 & A little impact & 9 & 5.2 \\
Concerned & 44 & 25.4 & Impact & 29 & 16.8 \\
Very concerned & 76.8 & 43.9 & A lot of impacts & 66 & 38.2 \\
Extremely concerned & 48 & 27.7 & A high impact & 63 & 36.4 \\
Total & 173 & 100.0 & Total & 173 & 100.0 \\
\hline
\end{tabular}


The majority of the $74.6 \%(n=129)$ of the participants report that the COVID-19 pandemic will have a quite high impact on their academic journey.

\subsection{Schedule, Place, and Specific Isolation Moments to Study}

Regarding the study schedule, as can be seen in Table $4,70.5 \%(n=122)$ of the participants reported not having a specific Schedule. Regarding the specific place of study, there seems to be greater stability since most of the answers were "always" ( $\mathrm{n}=71 ; 41.0 \%)$. The specific moments of isolation to study seem to have been achieved quite often or always for $46.8 \%(n=81)$ of the participants (Table 4$)$.

Table 4. Schedule, place, and specific isolation moments to study.

\begin{tabular}{ccccccc}
\hline Variables & \multicolumn{2}{c}{ Study Schedule } & \multicolumn{2}{c}{ Place of Study } & \multicolumn{2}{c}{ Moments of Isolation } \\
\hline Answers & Frequency & $\mathbf{\%}$ & Frequency & $\mathbf{\%}$ & Frequency & $\mathbf{\%}$ \\
\hline Never & 27 & 15.6 & 13 & 7.5 & 17 & 9.8 \\
A few times & 31 & 17.9 & 16 & 9.2 & 27 & 15.6 \\
Sometimes & 64 & 37.0 & 39 & 22.5 & 48 & 27.7 \\
Quite often & 24 & 13.9 & 34 & 19.7 & 50 & 28.9 \\
Always & 27 & 15.6 & 71 & 41.0 & 31 & 17.9 \\
Total & 173 & 100.0 & 173 & 100.0 & 173 & 100.0 \\
\hline
\end{tabular}

\subsection{Higher Education Institution (HEI) and Its Previous and Current Level of Preparation}

Table 5 shows the perception of the higher education institution's level of preparation and adaptation concerning the COVID-19 pandemic. Regarding the institution's level of preparation, $120(64.4 \%)$ of the inquired reported between nothing and partially prepared. Regarding the level of adaptation, at this moment, most of the answers $(n=90 ; 52 \%)$ are found between very and fully adapted.

Table 5. Level of preparation and adaptation of the institution concerning the COVID-19 pandemic.

\begin{tabular}{ccccc}
\hline \multicolumn{1}{c}{ Variables } & \multicolumn{2}{c}{ Level of Preparation } & \multicolumn{2}{c}{ Level of Adaptation } \\
\hline \multicolumn{1}{c}{ Answers } & Frequency & \% & Frequency & \% \\
\hline Nothing prepared/adapted & 32 & 18.5 & 12 & 6.9 \\
Poorly prepared/adapted & 43 & 24.9 & 26 & 15.0 \\
Partly prepared/adapted & 45 & 26.0 & 45 & 26.0 \\
Very prepared/adapted & 45 & 26.0 & 67 & 38.7 \\
Fully prepared/adapted & 8 & 4.6 & 23 & 13.3 \\
Total & 173 & 100.0 & 173 & 100.0 \\
\hline
\end{tabular}

\subsection{The Experience on Distance Learning}

Regarding the course of their studies, the majority of participants were having online classes instead of face-to-face teaching $(\mathrm{n}=170 ; 98.3 \%)$, considering that for $94.8 \%$, it was their first experience of online classes.

Students are satisfied with the online class format (Table 6).

Table 6. Satisfaction with the online classes format.

\begin{tabular}{lccc}
\hline $\begin{array}{c}\text { Satisfaction with the } \\
\text { Online Classes Format }\end{array}$ & Frequency & $\%$ & Mode \\
\hline Not satisfied at all & 24 & 13.9 & \\
Not very satisfied & 37 & 21.4 & \\
Satisfied & 60 & 34.7 & 3 = Satisfied \\
Very satisfied & 35 & 20.2 & \\
Totally satisfied & 17 & 9.8 & \\
$\quad$ Total & 173 & 100.0 & \\
\hline
\end{tabular}


When questioned if they dedicated their time to study in the online format more than they would in a face-to-face format, the answers are well-balanced with $53.2 \%(n=92)$ saying no while $46.8 \%$ of participants $(n=81)$ saying yes (Table 7).

Table 7. Estimation of more study time involved in the online learning process compared with face-a-face learning process.

\begin{tabular}{ccc}
\hline Answers & Frequency & $\%$ \\
\hline Yes & 81 & 46.8 \\
No & 92 & 53.2 \\
Total & 173 & 100.0 \\
\hline
\end{tabular}

Regarding the equipment used, most participants use a laptop with more regularity $(n=167$; 62.1\%) (Table 8).

Table 8. Equipment used more frequently by the students.

\begin{tabular}{lcc}
\hline \multicolumn{1}{c}{ Equipment } & Frequency & \% \\
\hline Desktop computer & 10 & 3.7 \\
Laptop & 167 & 62.1 \\
Tablet & 26 & 9.7 \\
Smartphone & 66 & 24.5 \\
$\quad$ Total & 269 & 100.0 \\
\hline
\end{tabular}

In terms of the tools used by Professors, the most used was the International Communication Platform (e.g., Zoom, Google Hangouts ... ) $(\mathrm{n}=168 ; 41.8 \%$ ) and e-mail $(\mathrm{n}=146 ; 36.3 \%)$ (Table 9).

Table 9. Online Learning Tools.

\begin{tabular}{lcc}
\hline \multicolumn{1}{c}{ Online Learning Tools } & Frequency & \% \\
\hline E-mail & 146 & 36.3 \\
Smartphone/Videochat & 31 & 7.7 \\
\hline International Communication Platform & 168 & 41.8 \\
$\begin{array}{l}\text { (e.g., Zoom, Google Hangouts ... ) } \\
\text { E-Learning Platform or a similar tool }\end{array}$ & 57 & 14.2 \\
\multicolumn{1}{r}{ Total } & 402 & 100.0 \\
\hline
\end{tabular}

The participants point out the use of the conference resource (video and audio) as a means of communication facilitating the learning process (Table 10).

Table 10. Communication facilitators.

\begin{tabular}{lcc}
\hline Communication Facilitators & Frequency & $\mathbf{\%}$ \\
\hline Conference Calls & 12 & 6.9 \\
Chat - chatroom & 6 & 3.5 \\
Conferences (video and audio) & 129 & 74.6 \\
Electronic Mail & 21 & 12.1 \\
Discussion forums & 5 & 2.9 \\
\multicolumn{1}{c}{ Total } & 173 & 100.0 \\
\hline
\end{tabular}

The replies show that a diversity of pedagogical techniques was used, as the clarification sessions' expression, availability of pedagogical materials in video and text format as well as group work (Table 11). 
Table 11. Pedagogical techniques used.

\begin{tabular}{|c|c|c|}
\hline Pedagogical Techniques & Frequency & $\%$ \\
\hline Clarification sessions & 136 & 18.0 \\
\hline Availability of pedagogical materials in video format & 133 & 17.6 \\
\hline Availability of pedagogical materials in text format & 116 & 15.3 \\
\hline Group work & 114 & 15.1 \\
\hline Individual work & 72 & 9.5 \\
\hline Small groups discussion & 61 & 8.1 \\
\hline Availability of pedagogical materials in audio format & 45 & 5.9 \\
\hline Large groups discussion & 30 & 4.0 \\
\hline Pedagogical games & 29 & 3.8 \\
\hline Simulations / role-play & 19 & 2.5 \\
\hline Case studies & 2 & 0.30 \\
\hline Total & 757 & 100 \\
\hline
\end{tabular}

When questioned about the balance of this online teaching experience, the viewpoints differ, positioning themselves between the scale's midpoint and a slight positive connotation. This result of ambiguous position is reinforced when questioned if they consider that face-to-face teaching's replacement by distance learning methodologies had a positive result with $51.4 \%(n=89)$ saying yes and $48.6 \%(n=84)$ saying no, as well as when questioned about this format's maintenance in the following school year, $56.1 \%(n=97)$ saying yes and $43.9 \%(n=76)$ saying no.

The issue of the maintenance of the format was complemented with the justification request which was the content analysis' subject. The reasons pointed out for not wanting to maintain the format are associated with the reconciling difficulty of this format with practical classes, technological constraint, especially the internet one, and the need for social proximity with colleagues and Professors. The reasons pointed out to support this format's continuity are associated with the security made possible while in a pandemic and time and location's flexibility (Tables 12 and 13).

Table 12. Balance of the online teaching experience.

\begin{tabular}{lcc}
\hline \multicolumn{1}{c}{ Balance } & Frequency & $\%$ \\
\hline Very negative, was far below expectations & 14 & 8.1 \\
Negative & 26 & 15.0 \\
Reasonable & 55 & 31.8 \\
Positive & 53 & 30.6 \\
Very positive, has far exceeded expectations & 25 & 14.5 \\
$\quad$ Total & 173 & 100.0 \\
\hline
\end{tabular}

Table 13. Balance and maintenance of the online format.

\begin{tabular}{ccccc}
\hline Variables & $\begin{array}{c}\text { A Positive Result of Replacing } \\
\text { Face-To-Face Education with Distance } \\
\text { Learning Methodologies }\end{array}$ & \multicolumn{2}{c}{$\begin{array}{c}\text { Maintenance of The Online } \\
\text { Format in The Next School Year }\end{array}$} \\
\hline Answers & Frequency & $\%$ & Frequency & $\%$ \\
\hline No & 84 & 48.6 & 76 & 43.9 \\
Yes & 89 & 51.4 & 97 & 56.1 \\
Total & 173 & 100.0 & 173 & 100.0 \\
\hline
\end{tabular}

The most pointed out were online tests $(n=145 ; 42.9 \%)$, followed by individual ( $n=97 ; 28.7 \%)$ and group $(\mathrm{n}=84 ; 24.9 \%)$ online works, with students being reasonably satisfied $(\mathrm{n}=66 ; 38.2 \%)$ and very satisfied $(\mathrm{n}=48 ; 27.7 \%)$ about the evaluation's format (Tables 14 and 15$)$. 
Table 14. Evaluation method.

\begin{tabular}{|c|c|c|}
\hline Evaluation Method & Frequency & $\%$ \\
\hline Face-to-face & 8 & 2.4 \\
\hline Online through individual work & 97 & 28.7 \\
\hline Online through group work & 84 & 24.9 \\
\hline Online tests & 145 & 42.9 \\
\hline Others & 4 & 1.2 \\
\hline Total & 338 & 100 \\
\hline
\end{tabular}

Table 15. Evaluation's format satisfaction.

\begin{tabular}{lcc}
\hline \multicolumn{1}{c}{ Satisfaction } & Frequency & $\mathbf{\%}$ \\
\hline Not satisfied at all & 13 & 7.5 \\
Not very satisfied & 29 & 16.8 \\
Reasonably satisfied & 66 & 38.2 \\
Very satisfied & 48 & 27.7 \\
Extremely satisfied & 17 & 9.8 \\
$\quad$ Total & 173 & 100.0 \\
\hline
\end{tabular}

\subsection{Opinions on Online Teaching}

The participants positioned their agreement level with a set of statements on a five-point scale where 1 represents "I totally disagree" and 5 represents "I totally agree". The means' analysis allows us to verify that students report numbers above the scale's midpoint on their preference for the face-to-face format (mean $=3.82$ ) and that this format requires significant changes for the students $($ mean $=3.62)$ (Table 16).

Table 16. Opinions on online teaching.

\begin{tabular}{ccc}
\hline Opinions & Mean & Standard Deviation \\
\hline I prefer the face-to-face classes format & 3.82 & 1.385 \\
Online teaching allows me to save time & 3.62 & 1.153 \\
Online teaching requires significant changes for the student & 3.42 & 1.435 \\
Online teaching is more functional in terms of schedules & 3.4 & 1.363 \\
I felt comfortable with online classes & 3.38 & 1.263 \\
classes' contents & 3.38 & 1.168 \\
The execution of asynchronous tasks is useful to assure the learning of the & 3.23 & 1.258 \\
My Higher Education Institution has always sought the best for all students & 3.02 & 1.215 \\
Asynchronous tasks between synchronous classes make it easier to & 1.304 \\
concentrate in class & 2.44 & 1.433 \\
\hline I believe I learn the same in either online or face-to-face classes & 2.39 & \\
\hline
\end{tabular}

\subsection{Obstacles Involved in the Online Learning Process}

Participants were asked to highlight the obstacles involved in the online learning process. The obstacles listed were highlighted 851 times by the participants and only 16 of them considered not to have obstacles. It is possible to highlight the excess of activities and works proposed $(n=112$; $19.9 \%)$ and lack of concentration $(\mathrm{n}=109 ; 12.6 \%)$ (Table 17).

\subsection{Advantages Involved in the Online Learning Process}

Participants were asked to indicate the advantages involved in the online learning process. The advantages listed were noted 417 times by the participants and only 19 participants considered that there were no advantages. The flexibility of location $(n=133 ; 30.5 \%)$ and time $(n=91 ; 20.9 \%)$ stands out (Table 18). 
Table 17. Obstacles involved in the online learning process.

\begin{tabular}{lcc}
\hline \multicolumn{1}{c}{ Obstacles } & Frequency & $\%$ \\
\hline Excess of activities and works proposed & 112 & 12.9 \\
Lack of concentration & 109 & 12.6 \\
Lack of students' interaction & 87 & 10.0 \\
Difficulty in time management & 72 & 8.3 \\
Lack of technology skills by Professors & 70 & 8.1 \\
Difficulty in balancing family and academic life & 68 & 7.8 \\
Lack of motivation and effort by students and families & 67 & 7.7 \\
Lack of support from Professors & 56 & 6.5 \\
Lack of support from the Higher Education Institution & 50 & 5.8 \\
Lack of motivation and effort by Professors & 46 & 5.3 \\
Lack of equipment by students & 31 & 3.6 \\
Lack of support from the Government and the Ministry & 28 & 3.2 \\
Lack of equipment by Professors & 18 & 2.1 \\
Additional costs with equipment & 17 & 2.0 \\
Lack of technology skills by students & 16 & 1.8 \\
Other obstacles & 4 & .50 \\
No obstacles & 16 & 1.8 \\
\multicolumn{1}{c}{ Total } & 867 & $100.0 \%$ \\
\hline
\end{tabular}

Table 18. Advantages involved in the online learning process.

\begin{tabular}{|c|c|c|}
\hline Advantages & Frequency & $\%$ \\
\hline Time flexibility & 91 & $20.9 \%$ \\
\hline Location flexibility & 133 & $30.5 \%$ \\
\hline It was a contribution to more easily manage confinement & 86 & $19.7 \%$ \\
\hline Best academic results & 54 & $12.4 \%$ \\
\hline Ease of managing family and professional tasks with the course & 49 & $11.2 \%$ \\
\hline Other advantages & 4 & $0.9 \%$ \\
\hline No advantages & 19 & $4.4 \%$ \\
\hline Total & 436 & $100.0 \%$ \\
\hline
\end{tabular}

\subsection{Relationship Pandemic and Distance Learning Experience}

The mode analysis reveals that students are reasonably satisfied (point 3 in answer scale) with the online format and the evaluation's format and consider HEI partly prepared (point 3 in answer scale) to deal with COVID-19. Students also reveal a lot of concern with the impact of the pandemic situation on the academic journey (point 4 in answer scale) and consider HEI to be well adapted (point 4 in answer scale).

Through Spearman's rho analysis (Table 19), it was found a statistically significant and inverse correlation between pandemic impact on the academic journey and all the other variables, thus the more students perceive the impact of the pandemic on academic life, the less they are satisfied with the online experience and evaluation; Balance of the online teaching experience is less positive, as well as the level of adaptation. On the other hand, there are positive and significant correlations between satisfaction with the online classes format and evaluation's format, level of preparation, and adaptation of HEI.

Table 19. Mode and Correlations.

\begin{tabular}{|c|c|c|c|c|c|c|}
\hline Variables & Mode & 1 & 2 & 3 & 4 & 5 \\
\hline 1. Satisfaction with the online classes format & 3 & & & & & \\
\hline 2. Pandemic impact on the academic journey & 4 & $-0.495^{* *}$ & & & & \\
\hline 3. Level of preparation of the HEI concerning the COVID-19 & 3 & $0.360 * *$ & -0.139 & & & \\
\hline 4. Level of adaptation of the HEI concerning the COVID-19 & 4 & $0.280 * *$ & $-0.183^{* *}$ & $0.412^{* *}$ & & \\
\hline 5. Evaluation's format satisfaction & 3 & $0.596^{* *}$ & $-0.349 * *$ & $0.179 * *$ & $0.193^{* *}$ & \\
\hline 6. Balance of the online teaching experience & 3 & $0.764 * *$ & $-0.487^{* *}$ & $0.279 * *$ & $0.303^{* *}$ & $0.665^{* *}$ \\
\hline
\end{tabular}


Due to the pandemic situation and the probable necessity of maintenance of the online format in the next school year, it has explored the differences between groups based if they want or do not want to maintain the online format in the next school year (Table 20).

Table 20. Differences between a student that want or do not want to maintain the online format on the next school year.

\begin{tabular}{cccccc}
\hline Variables & $\begin{array}{c}\text { Maintenance of the } \\
\text { Online Format in } \\
\text { the Next } \\
\text { School Year }\end{array}$ & N & Mean & $\begin{array}{c}\text { Standard } \\
\text { Deviation }\end{array}$ & T-Test \\
\hline $\begin{array}{c}\text { Pandemic impact on the } \\
\text { academic journey }\end{array}$ & No & 76 & 4.36 & 0.743 & $\mathrm{t}_{(166.399)}=-4.580, p=0.000$ \\
\hline Level of preparation of the & No & 97 & 3.70 & 1.129 & $\mathrm{t}_{(152.819)}=-1.268, p=0.207$ \\
HEI concerning the COVID-19 & Yes & 97 & 2.61 & 1.234 & \\
\hline Level of adaptation of the HEI & No & 76 & 3.22 & 1.103 & $\mathrm{t}_{(171)}=-1.485, p=0.139$ \\
concerning the COVID-19 & Yes & 97 & 3.47 & 1.100 & \\
\hline Satisfaction with the online & No & 76 & 2.24 & 0.978 & $\mathrm{t}_{(171)}=-7.751, p=0.000$ \\
classes format & Yes & 97 & 3.43 & 1.030 & \\
\hline Evaluation's & No & 76 & 2.62 & 0.993 & $\mathrm{t}_{(171)}=-6.604, p=0.000$ \\
format satisfaction & Yes & 97 & 3.58 & 0.911 & \\
\hline Balance of the online & No & 76 & 2.59 & 1.073 & $\mathrm{t}_{(140.823)}=-8.187, p=0.000$ \\
teaching experience & Yes & 97 & 3.82 & 0.854 & \\
\hline
\end{tabular}

Students who intend to maintain the online format rate the pandemic as having the least impact on the academic journey (mean $=3.70)$, are more satisfied with the online format (mean $=3.43$ ) and with the evaluation's format (mean $=3.58$ ) and make a more positive balance of the previous experience (mean $=3.82$ ). No difference was found in the assessment of the preparation and adaptation of the institutions.

\section{Conclusions}

The pandemic has brought exceptional circumstances to teaching that require questioning the teaching methodologies used. To this end, a questionnaire with two sections was prepared, the first related to the distance learning experience during the hospitalization period by COVID-19 and the second composed of a set of sociodemographic and socio-academic characteristics.

This context was new and different-for $94.8 \%$ of the sample, it was the first experience with online classes. In general, students showed an ambivalent position concerning distance learning. Online is important to them given their concern about the pandemic and as a protector in this context. The results would be different in a non-pandemic context.

In terms of logistics and form issues, we can assume there is a lack of specific hours $70.5 \%$ ( $n=122)$ of the participants reported not having a specific time and only $(n=71 ; 41.0 \%)$ always uses the same place of study/classes, which translates into a huge difference compared to the face-to-face education system.

Regarding the preparation of the institutions, the majority considers that they were not prepared at all $(64.4 \%)$ for this change in functioning, but 52\% recognize that they have adapted a lot or totally.

Among the various tools used, the Teaching Institutions used more the international communication Platform (e.g., Zoom, Google Hangouts ...) (41.8\%) and the majority of participants used the laptop as equipment with more regular use $(n=167 ; 62.1 \%)$.

The analysis of the averages allows verifying that the students report values above the midpoint of the scale at the level of preference for the classroom format (average $=3.82$ ) and that this format requires significant changes for the student (average $=3.62$ ).

The barriers associated with the online regime listed were reported 851 times by the participants and only sixteen participants considered that there were no barriers. The excess of activities and 
work proposed $(\mathrm{n}=112 ; 19.9 \%)$ and the lack of concentration $(\mathrm{n}=109 ; 12.6 \%)$ were highlighted by the students.

The two main advantages associated with the online regime were the location flexibility $(n=133$; $30.5 \%)$ and time $(\mathrm{n}=91 ; 20.9 \%)$.

About Pedagogical Issues we have some respondents highlight the use of conferences (video and audio) as a means of communication that facilitates the learning process $(n=126 ; 74.6 \%)$.

The responses demonstrate that a variety of teaching techniques were used. The expression of the Sessions to clarify issues, the provision of teaching materials in video and text format stands out, as well as group work.

The issue of maintaining the format was complemented by the justification request that was the subject of content analysis. The reasons given for not wanting to keep the format are associated with the difficulty of reconciling this format with practical classes, technological constraints, namely, the Internet, and the need for social proximity with colleagues and teachers.

In terms of assessment, online tests were the most referenced $(n=145 ; 42.9 \%)$, followed by individual online work $(n=97 ; 28.7 \%)$ and in group work $(n=84 ; 24.9 \%)$, with the students being reasonably satisfied $(n=66 ; 38.2 \%)$ and very satisfied $(n=48$; students reasonably satisfied $(n=66$; $38.2 \%)$ and very satisfied $(\mathrm{n}=48 ; 27.7 \%)$ with the format of the assessments.

In short, from the analysis of the responses obtained, it seems to us that the greatest concern of the respondents is related to formal and contextual aspects concerning the regime of online classes. The analyzed values, taken as a whole, allow us to infer that there are acceptance and profit, in terms of knowledge, with this teaching regime. It is worth mentioning the context of uncertainty in which this transition took place, as well as the environment that surrounded this process.

The evaluation methodologies used were accepted and reveal a very wide range of choices on the part of the teaching teams and different preferences of the students, as in the classroom's teaching regime.

Results confirm the two first hypotheses to be essentially draws. Therefore, it there a negative correlation between the pandemic impact on the academic journey and the attitudes of Portuguese higher education students regarding compulsory digital and distance learning university. Therefore, the more the students perceive the pandemic as having an impact on their academic journey, the less they are satisfied with online class formats and evaluation formats, also the perception was less that HEI is prepared and adapted to the pandemic situation and was evaluated as the worst of the online teaching experience. As expected, if there was a positive correlation between the satisfaction with the online classes format and the attitudes of Portuguese higher education students regarding compulsory digital and distance learning university, this means that the more the students were satisfied with online classes, the more positive were their attitudes regarding pandemic impact, level of HEI preparation and adaptation, satisfaction with evaluation format and general balance of the experience. This result highlights the significance of education as a helpful mechanism to deal with emergency situations [39].

The third hypotheses were partially supported. No differences were found in the level of preparation and adaptation of HEI. However, results show that the students that want to maintain the online format in the next school year are those that are more satisfied with evaluation format and online class formats and that do a more positive general balance of the online teaching experience. This result points out that it is more valuable for students that pedagogical issues than the institutional aspects. Therefore, the intervention focus should be in this field, institutions should invest in teacher training and eLearning platforms.

The sample size should be reported as a limitation of the study; however, the focus was on having a heterogeneous sample and not prolonging data collection for too long in order to have some contributions to the new school year. Assuming that the larger the population size, the smaller the percentage of the population needed to get a representative sample [40] and considering the minimum value for the data analysis procedures it was aiming to perform [41]. During the pandemic, there was an intensification of research, which may have contributed to the failure to fill. Data collection took place 
at the beginning of the school year, which may have affected questionnaire adherence. In the future, it will be interesting to replicate this study throughout the school year, thus being able to function as a tool for monitoring distance learning. Therefore, by analyzing the online teaching experience, we can infer that the students who found it useful assigned an average of 3.82, a very significant value that represents availability to repeat the experience.

In terms of future research, it is important to understand the consequences of this type of teaching on the success of students, both in terms of the repetition of Curricular Units and in terms of the obtained classifications.

Author Contributions: This study was designed and carried out by all of the authors. All of the authors conceived, wrote, and revised several sections of the article. All authors have read and agreed to the published version of the manuscript.

Funding: This study was funded by Fundação para a Ciência e Tecnologia, Grant: UIDB/00315/2020.

Acknowledgments: The authors would like to acknowledge the participants in the study and the reviewers.

Conflicts of Interest: The authors declare no conflict of interest.

\section{References}

1. Almaiah, M.A.; Al-Khasawneh, A.; Althunibat, A. Exploring the critical challenges and factors influencing the E-learning system usage during COVID-19 pandemic. Educ. Inf. Technol. 2020, 25, 5261-5280. [CrossRef] [PubMed]

2. Sulisworo, D.; Rohmadheny, P.S.; Fatimah, N.; Arif, D.B.; Saifuddin, M.F. Learning analytics to predict student achievement in online learning during covid-19 mitigation. Int. J. Psychosoc. Rehabil. 2020, 24, 1844-1861.

3. Irawan, A.W.; Dwisona, D.; Lestari, M. Psychological Impacts of Students on Online Learning During the Pandemic COVID-19. Konseli J. Bimbing. Konseling 2020, 7, 53-60. [CrossRef]

4. Adnan, M. Online learning amid the COVID-19 pandemic: Students perspectives. J. Pedagog. Res. 2020, 1, 45-51. [CrossRef]

5. Allo, M.D. Is the online learning good in the midst of Covid-19 Pandemic? The case of EFL learners. J. Sinestesia 2020, 10, 1-10.

6. Mukhtar, K.; Javed, K.; Arooj, M.; Sethi, A. Advantages, limitations, and recommendations for online learning during the covid-19 pandemic era. Pakistan J. Med. Sci. 2020, 36. [CrossRef]

7. Çebi, A.; Güyer, T. Students' interaction patterns in different online learning activities and their relationship with motivation, self-regulated learning strategy and learning performance. Educ. Inf. Technol. 2020, 25, 3975-3993. [CrossRef]

8. Sousa, M.J.; Cruz, R.; Martins, J.M. Digital Learning Methodologies and Tools-A Literature Review. In Proceedings of the Edulearn17 Proceedings, Barcelona, Spain, 3-5 July 2017; pp. 5185-5192.

9. Sousa, M.J.; Rocha, Á. Corporate Digital Learning_Proposal of Learning Analytics Model. In Trends and Advances in Information Systems and Technologies; WorldCIST'18 2018, Advances in Intelligent Systems and Computing; Rocha, Á., Adeli, H., Reis, L.P., Costanzo, S., Eds.; Springer: Cham, Switzerland, 2018; Volume 745.

10. Barber, W.; King, S.; Buchanan, S. Problem Based Learning and Authentic Assessment. Electron. J. E-Learn. 2015, 13, 59-67.

11. Sousa, M.J.; Rocha, Á. Digital learning: Developing skills for digital transformation of organizations. Future Gener. Comput. Syst. 2019, 91, 327-334. [CrossRef]

12. Liyanagunawardena, T.R.; Lundgvist, K.; Williams, S.A. Who are with us: MOOC learners on a Future Learn course. Br. J. Educ. Technol. 2015, 46, 557-569. [CrossRef]

13. Liwen, C.; Tung-Liang, C.; Nian-Shing, C. Students' perspectives of using cooperative learning in a flipped statistics classroom. Australas. J. Educ. Technol. 2015, 31, 621-640.

14. Masterman, E. Bringing Open Education Practice to a Research-intensive University: Prospects and Challenges. Electron. J. E-Learn. 2016, 14, 31-42.

15. Salmon, G.; Gregory, J.; Lokuge, D.K.; Ross, B. Experiential online development for educators: The example of the Carpe Diem MOOC. Br. J. Educ. Technol. 2015, 46, 543-556. [CrossRef] 
16. Sohrabi, B.; Iraj, H. Implementing flipped classroom using digital media: A comparison of two demographically different groups perceptions. Comput. Hum. Behav. 2016, 60, 514-524. [CrossRef]

17. Stewart, B. Open to influence: What counts as an academic influence in scholarly networked Twitter participation. Learn. Media Technol. 2015, 40, 287-309. [CrossRef]

18. Thibaut, P.; Curwood, J.S.; Carvalho, L.; Simpson, S. Moving across physical and online spaces: A case study in a blended primary classroom. Learn. Media Technol. 2015, 40, 458-479. [CrossRef]

19. Trotskovsky and Sabag, N. One Output Function: A misconception of Students Studying Digital Systems-A case study. Res. Sci. Technol. Educ. 2015, 33, 131-142. [CrossRef]

20. $\mathrm{Xu}, \mathrm{H}$. Faculty use of a learning object repository in higher education. J. Inf. Knowl. Manag. Syst. 2016, 46, 469-478. [CrossRef]

21. McNaughton, S.M.; Westberry, N.C.; Billiot, J.M.; Gaeta, H. Exploring teachers' perceptions of videoconferencing practice through space, movement and the material and virtual environments. Int. J. Mult. Res. Approaches 2014, 8, 87-99. [CrossRef]

22. Martin-Garcia, M.; Serran, M.J.H.; Gomez, M. Fases y clasificación de adoptantes de blended learning en contextos universitarios. Aplicación del análisis CHAID. Rev. Española Pedagog. 2014, 72, 457-476.

23. Sungkur, R.K.; Panchoo, A.; Bhoyroo, N.K. Augmented Reality, the Future of Contextual Mobile Learning. Interact. Technol. Smart Educ. 2016, 13, 123-146. [CrossRef]

24. Tena, R.R.; Almenara, J.C.; Osuna, J.B. E-Learning of Andalusian University's Lecturers. Turk. Online J. Educ. Technol. 2016, 15, 25-37.

25. Friend, J.; Militello, M. Lights, Camera, Action: Advancing Learning, Research, and Program Evaluation through Video Production in Educational Leadership Preparation. J. Res. Leadersh. Educ. 2014, 10, 81-103. [CrossRef]

26. Guzman, G.; Hernandez, M.; Pirez, R. Uso de gestores de aprendizaje en el pregrado de la Universidad Nacional Abierta de Venezuela. Apert. Rev. Innovación Educ. 2014, 6, 60-75.

27. Kosonen, K.; Ilomaki, L.; Lakkala, M. Using a Modeling Language for Supporting University Students' Orienting Activity when Studying Research Methods. J. Interact. Media Educ. 2015, 1, 8. [CrossRef]

28. Lau, K.H. Computer-based teaching module design: Principles derived from learning theories. Med. Educ. 2014, 48, 247-254. [CrossRef]

29. Mantri, A. Working towards a scalable model of problem-based learning instruction in undergraduate engineering education. Eur. J. Eng. Educ. 2014, 39, 282-299. [CrossRef]

30. Moorefielf-Lang, H.; Hall, T. Instruction on the Go: Reaching Out to Students from the Academic Library. J. Libr. Inf. Serv. Distance Learn. 2015, 9, 57-68. [CrossRef]

31. Munoz Gonzales, J.M.; Rubio, S.G.; Pichardo, M.C. Strategies of Collaborative Work in the Classroom through the Design of Video Games. Digit. Educ. Rev. 2015, 27, 69-84.

32. Nielsen, W.; Hoban, G. Designing a Digital Teaching Resource to Explain Phases of the Moon: A Case Study of Preservice Elementary Teachers Making a Slowmation. J. Res. Sci. Teach. 2015, 52, 1207-1233. [CrossRef]

33. Rai, S.S.; Gaikwad, A.T.; Kulkarni, R.V. A Research Paper on Simulation Model for Teaching and Learning Process in Higher Education. Int. J. Adv. Comput. Res. 2014, 4, 582-587.

34. Rudow, J.; Sounny-Slitine, M.A. The Use of Web-Based Video for Instruction of GIS and Other Digital Geographic Methods. J. Geogr. 2015, 114, 168-175. [CrossRef]

35. Stansbury, J.A.; Earnest, D.R. Meaningful Gamification in an Industrial/Organizational Psychology Course. Teach. Psychol. 2017, 44, 38-45. [CrossRef]

36. Unger, R.; Kulhavy, D.L.; Busch-Petersen, K.; Hung, I.-K. Integrating Faculty-Led Service Learning Training to Quantify Height of Natual Resources from a Spacial Science Perspective. Int. J. Higher Educ. 2016, 5, 104-116. [CrossRef]

37. Wood, D.; Bilsborow, C. I Am Not a Person with a Creative Mind: Facilitating Creativity in the Undergraduate Curriculum through a Design-Based Research Approach. Electron. J. E-Learn. 2014, 12, 111-125.

38. Collison, G.; Elabaum, G.; Haavind, S.; Tinher, R. Facilitating Online Learning \pm Effective Strategies for Moderators; Atwoood Publishing: Madison, WI, USA, 2000.

39. Sinclair, M. Education in Emergencies. In Learning for a Future: Refugee Education in Developing Countries; Crisp, J., Talbot, C., Cipollone, D.B., Eds.; United Nations High Commissioner for Refugees: Geneva, Switzerland, 2001; pp. 1-83. 
40. Leedy, P.D. Pratical Researche: Planning and Design; Prentice-Hall, Inc.: Upper New Jersey, NJ, USA, 1997.

41. Hill, M.M.; Hill, A. Investigação Por Questionário; Researche by Questionnaire; Edições Sílabo: Lisboa, Portugal, 2008.

Publisher's Note: MDPI stays neutral with regard to jurisdictional claims in published maps and institutional affiliations.

(C) 2020 by the authors. Licensee MDPI, Basel, Switzerland. This article is an open access article distributed under the terms and conditions of the Creative Commons Attribution (CC BY) license (http://creativecommons.org/licenses/by/4.0/). 